\title{
Strategic Thinking in Jordan: Still Crafting the Architecture?
}

\author{
Mohammad N. D. Al.marshad \\ Princess Alia University College, Al-Balqa Applied University, Amman, PO Box 942303, Jordan
}

\begin{abstract}
This is one of the first studies of the practice of strategic thinking skills in an emerging market. The purpose of this study is to investigate the the practice of strategic thinking by Jordanian industrial companies registered on the Amman Stock Exchange (ASE) and the relationship between the dimensions of strategic thinking and certain organizational characteristics (age, size and type of ownership). A review of the literature relating to strategic thinking and strategic thinking skills in both developed and emerging markets was undertaken. A questionnaire survey of three levels of management in each Jordanian industrial company was undertaken. A 52 per cent response rate was achieved. The main findings of this study are that Jordanian industrial companies engage in strategic thinking by using reflecting, reframing and systems thinking skills. The managers of these companies at three different levels have positive attitudes towards the practice of strategic thinking and believe in the efficacy of most of the strategic thinking skills surveyed. There is a positive significant relationship between the use of systems thinking skills and type of ownership but a less clear relationship with the age and size of the company. The use of reflecting thinking skills has an unclear relationship with the size of company and is not related to age and ownership type. The use of reframing thinking skills has an unclear relationship with age and type of ownership and is not related to the size of company. Future research could be conducted by using in-depth types of study that focus on a smaller number of respondents, as well as a smaller number of these companies. Future research should investigate the relationship between strategic thinking and the culture, structure, performance and decision making of medium and small size industrial companies in Jordan.
\end{abstract}

Keywords: Strategic thinking; Industrial companies; Jordan; Strategic thinking; Organizational characteristics. DOI: $10.7176 / \mathrm{EJBM} / 11-26-08$

Publication date:September $30^{\text {th }} 2019$

\section{Introduction}

Strategic thinking can be defined "....as a process in which a person is perceiving, reflecting, feeling, realizing and acknowledging signs that impact on the future of the firm, giving them meaning and acting upon them by shaping the impressions, perspectives and behaviour accordingly" (Jelenc and Swiercz, 2011, p.7). There is widespread agreement that applying strategic thinking in organizations is important for their direction and sustainability (Goldman et al., 2015; Bonn, 2001; Liedtka, 1998a) and that its output is the discovery of novel and imaginative strategies (Goldman et al., 2015; Heracleous, 1998). Strategic thinking provides the ability to build competencies to control future markets (Hamel and Prahalad 1994), gain competitive advantage (Allio, 2006; O'Shannassy, 2001; Liedtka, 1998a) and it is a synthesis process, which involves intuition and creativity and its outcome is "an integrated perspective of the enterprise, a not-too-precisely articulated vision of direction" (Mintzberg, 1994b p.108).

Most of the research on strategic thinking has been undertaken in developed economies (Goldman and Scott 2016; Goldman et al., 2015; Moon, 2013; Pang and Pisapia, 2012; Karğin and Aktaş, 2012; Halis et al., 2010; Pisapia et al., 2009; Pisapia et al., 2005; Stonehouse and Pemberton, 2002; Bonn, 2001). Hardly any studies have reported on strategic thinking processes in emerging markets in general and in Jordan in particular (Salih and Alnaji, 2014; Karimi et al., 2014). An emerging market context, like Jordan, may yield insights that are not available in developed economies.

The aim of this study is to identify the practice of strategic thinking in Jordanian industrial companies that are registered on the Amman Stock Exchange. More specifically, the objectives of this research are twofold: (a) to investigate the extent of the practice of strategic thinking in Jordanian industrial companies and (b) to explore the relationship between organizational characteristics (age, size and type of ownership) that influence the practice of strategic thinking in Jordanian industrial companies.

Jordan is an Arab Kingdom in the Middle East, and is a small country which occupies an area of 96188 square kilometres with a population estimated in 2016 at 9.7 million inhabitants which is 80 per cent urban (World Bank Group, 2018; Department of Statistics Jordan, 2017). The Jordan economy is free market oriented and the ownership of enterprises is largely private, with the exception of public sector involvement in the mining industry (phosphates and potash) (USAID/Jordan, 2013; Amman Trade Point, 2009). The Jordanian economy depends on international aid and remittances from expatriates (Index of Economic Freedom Score, 2013). Industrial companies are key drivers of the Jordanian economy and are one of its largest employers. Wars in Syria and Iraq have affected Jordanian industrial companies, which have also provided a major shock to the domestic economy. Therefore, industrial companies in Jordan need to be highly adaptable to a changing environment in order to keep growing 
and compete with other industrial organizations inside and outside Jordan. This may include the use of different skills to lead their organizations strategically and to deal with the challenges and changes taking place in the business environment.

\section{Literature review}

\subsection{Strategic Thinking}

There is no agreed definition of the term "strategic thinking" (Tavakoli and Lawton, 2005; Heracleous, 2003; O’Shannassy, 2003; Bonn, 2001; Lawrence, 1999; Heracleous, 1998; O’Shannassy, 2001; Lawrence, 1999; Kustschera and Ryan, 2009; O'Shannassy, 1999). Many authors have used the concept of strategic thinking interchangeably with other concepts such as strategic management and strategic planning (Mainardes, Ferreira and Raposo, 2014; Salih and Alnaji, 2014; Bonn 2001; Liedtka 1998a; Wilson 1994), and this has created significant confusion in the literature (Goldman and Casey, 2010; Casey and Goldman, 2010; Steiner et al., 1983). Some think that the expression "strategic thinking" describes all thinking in relation to strategy, rather than to indicate a specific way of thinking with precise characteristics (Liedtka, 1998a). Wilson (1994 p.14) observed that: "this continuing search for improvement has profoundly changed the character of strategic planning so that it is now more appropriate to refer to it as strategic management or strategic thinking". The term strategic thinking was widely used at the end of the twentieth century (Allio, 2006; O'Shannassy, 2001; Liedtka, 1998a) and the term has been associated with an attempt by an organization to strengthen or gain competitive advantage. Indeed the existence of this relationship to competitive advantage gave prominence to the term "strategic thinking" (Baloch and Inam, 2007; Abraham, 2005; Bonn, 2005; Raimond, 1996; Bonn and Christodoulou, 1996; Mintzberg, 1994b; Wilson, 1994).

Some authors have differentiated between strategic planning and strategic thinking (Mainardes, Ferreira and Raposo, 2014; Heracleous, 1998; Liedtka 1998a; Mintzberg, 1994a; Mintzberg, 1994b; Liedtka, 1998b; Graetz, 2002). For instance, the role of strategic planning is "to realise and support strategies developed through the strategic thinking process and integrate these back into the business". In contrast, the role of strategic thinking is "to seek innovation and imagine new and very different futures that may lead a company to redefine its core strategies and even its industry" (Graetz, 2002 p. 457). Indeed, according to Mason (1986), the strategic thinking process includes all stages of strategic management that precede the strategic planning process, while Kustschera and Ryan (2009), Liedtka (1998a) and Mintzberg (1994a) indicate that strategic thinking is a way of thinking which is characterized by specific properties (Figure 1). Its outcome is an integrated perspective of the organization (Mintzberg, 1994b) which accords with the view of Hamel and Prahalad (1994) who used the term "crafting strategic architecture" to denote the concept of strategic thinking.

Fig. 1: The properties of strategic thinking

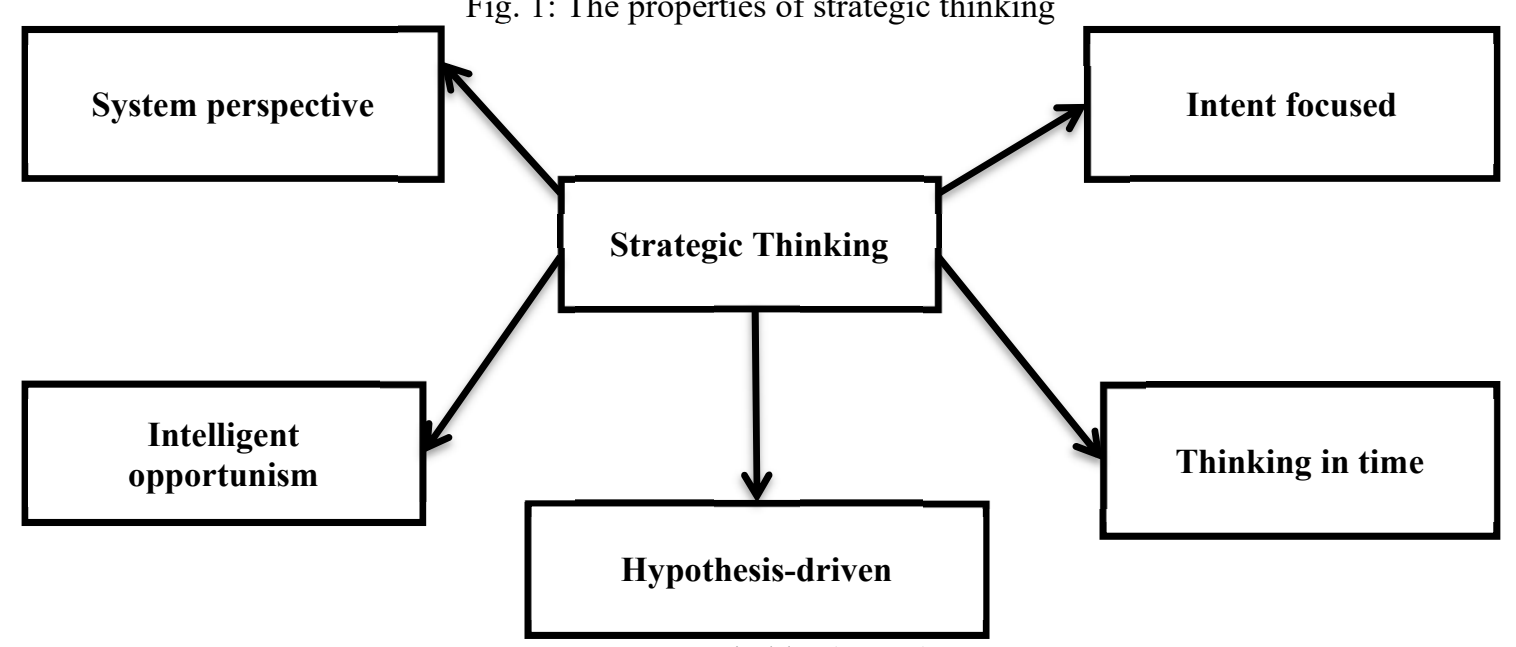

Source: Liedtka (1998a)

Heracleous (1998) and Mintzberg (1994a, 1994b) state that strategic thinking is a synthesizing process which results in the effective deployment of intuition and creativity in the formulation of strategic directions for an organization, while strategic planning is the analytical procedure aimed at the programming of pre-identified strategies which it has adopted. Strategic thinking refers to the deployment of the skills and abilities, which are necessary for an individual to undertake strategic management tasks (Alsallem, 2005). Therefore, strategic thinking is concerned with solving strategic issues and conceptualizing the future of an organization (Bonn, 2005 and O'Shannassy, 2001, 2003). The solving of strategic issues may take place at all levels of the organization (Monnavarian et al., 2011; Goldman, 2008; Tavakoli and Lawton, 2005; O'Shannassy, 2003; Graets, 2002; O'Shannassy, 2001; Mintzberg, 1994a; Mason, 1986). In other words, individuals at all levels of management in an organization - not just senior managers - can share thoughts, analysis and action and think strategically 
(Goldman, 2008; O'Shannassy, 2003). Organizations that succeed in addressing strategic thinking at all management levels should be able to improve their decision-making processes, resulting in higher quality strategies and greater competitive advantage (Bonn, 2005).

It is possible to define the term strategic thinking in a "broad" or a "narrow" way. The narrow definition concentrates on Eastern, creative, generative, divergent, synthetic thinking processes, while the broad definition tries to connect these thought processes with Western, analytical, rational, convergent thinking processes. The former view is linked with Mintzberg (1994a, 1994b) whereas the latter view is linked with writers such as Bonn (2005); O’Shannassy (2001); Liedtka (1998a); Raimond (1996); and Wilson (1994).

Raimond (1996 p.212) compared strategic thinking processes in Eastern and Western organizations. He divided the process of strategic thinking into two types: strategy as "intelligent machine", which depends on collecting data and processing them to be used as information to determine the main critical factors in the external environment, and "strategy as creative imagination", which depends on our imaginations "where we ideally want to be in, say, 10 or 20 years' time”.

\subsection{The Dimensions of Strategic Thinking}

There are a number of different types of strategic thinking skills which are associated with the practice of strategic thinking in organizations (Torkamani and Maymand 2016; Al-Zu'bi 2016; Goldman et al., 2015; Khalili et al., 2015; Khalili et al. 2015; Moon, 2013; Karğin and Aktaş 2012; Turkay et al., 2012; Pang and Pisapia, 2012; Monnavarian et al., 2011; Pisapia et al., 2011; Halis et al., 2010; Goldman, 2009; Gallen, 2006; Pisapia et al., 2005; Bonn, 2005; Bonn, 2001). Three thinking skills, or cognitive processes, have been identified as being of particular importance (Pang and Pisapia, 2012; Karğin and Aktaş 2012; Turkay et al., 2012; Halis et al., 2010; Pisapia et al., 2005). These are systems thinking skills, reframing thinking skills and reflecting thinking skills. They complement each other and are a potential way to distinguish between successful leaders and less successful leaders (Pisapia et al., 2005) and, by implication, organisations.

Systems thinking relates to a leader's ability to see systems holistically, by understanding the properties, forces, patterns and interrelationships which shape the behaviour of the system, and which therefore provides alternatives for action. Reflecting thinking means the capability to weave logical and rational thinking, by the use of perceptions, experience and information, to make judgments on what has happened, and to create intuitive principles that direct future actions. Reframing thinking relates to the leader's capability to switch attention across multiple perspectives, frames, mental models, and paradigms to generate new insights and alternatives for taking action.

Many scholars have identified the benefit of applying strategic thinking skills. For instance, Pisapia et al. (2005), Bonn (2005) and Bonn (2001) asserted that managers are able to develop unique choices and novel ideas through the application of reframing thinking skills. In addition, their use is central to the discovery of strategies and goals relating to the needs of their organizations. Pisapia et al. (2009) considered that the use of reframing thinking skills was a conscious effort by managers to switch attention to multiple perspectives in order to create new insights and choices for action. These skills allowed one to sort through problems and opportunities, to see the problems in ways that enable them to map out alternative strategies and to determine trends before others see them. Pang and Pisapia (2012) and Pisapia et al. (2009) asserted that reflective thinking skills enable individuals to use experience, perception and knowledge to understand problems, to think about the problems and inform actions. Reflective thinking enables them to use experience and perceptions to make judgments regarding what has happened in the past and is happening in the present to help them to guide their future actions. The benefits of applying systems thinking skills gives managers the ability to see systems holistically and through an understanding of their properties and forces to see patterns and interrelationships which provide choices for actions (Pisapia et al., 2009; Pisapia et al., 2005). In this context, Kaufman (1991, p.69) stated that strategic thinking may be characterized as "a switch from seeing the organization as a splintered conglomerate of disassociated parts (and employees) competing for resources, to seeing and dealing with the corporation as a holistic system that integrates each part in relationship to the whole".

Bonn (2005) emphasized that strategic thinking is an integrative process that consists of different elements. These elements include systems thinking, creativity and vision. Abraham (2005) identified five approaches to the practice of strategic thinking processes and the stretching of company thinking about different ways to compete, to deliver customer value and to grow. These approaches included differentiation, emulating entrepreneurs, finding new opportunities, being future-oriented, and being collaborative.

Al-Zu'bi (2016) conducted a study of Islamic banks in Jordan to determine the impact of strategic thinking competencies on the achievement of strategic flexibility and to determine the extent of the availability of strategic thinking and strategic flexibility. The study highlighted three competencies of strategic thinking: systems thinking, innovative thinking, and thinking-oriented vision. The measured strategic thinking competencies are based on Moon (2013) and the strategic flexibility variable is based on Matheson and Matheson (2011).

Khalili et al. (2015) conducted a study in the Ilam municipality in Iran to investigate the effects of strategic 
thinking on organizational performance. The study highlighted five dimensions of strategic thinking that Liedtka (1998a) had developed, based on the views of Mintzberg (1994b) on strategic thinking: systems perspective, intent focus, intelligent opportunism, hypotheses driven and thinking in time. The results indicate that strategic thinking and its dimensions had a statistically significant effect on organizational performance.

Pang and Pisapia (2012) investigated the extent to which Hong Kong uses strategic thinking skills to identify effective school leaders. They measure the extent of the use of strategic thinking skills among school leaders: systems thinking, reflecting, and reframing. They found that Hong Kong schools used strategic thinking skills, but there were differences in the extent of the use of these skills. The study found that the main concern of the principals was to sustain a fit between internal organizational operations and the external environment in order to establish organizational flexibility. Moreover, at this level, principals saw the systems in a holistic way although they used systems and reframing thinking the most frequently. At the vice principal level, the main concentration was on improving operations, conflict management, creating alignment, keeping focused, communication and relationships development. Furthermore, the study found that strategic thinking skills were used to a greater degree by principals of secondary schools than principals of primary schools, while vice principals in primary schools used reflection and systems thinking to a greater degree than the principals of the secondary schools. The study also investigated the effect of organizational and personal characteristics on these skills, as well as the link between strategic thinking skills and school leader effectiveness.

Ghorbani and Kiani (2012) highlighted five components of strategic thinking in their research model which had been established by Liedtka (1998a; 1998b), based on Mintzberg's (1994) theories to evaluate organizational readiness for change, in a study in the Mashhad Municipality in Iran. The components include systematic attitudes or views, a focus on goals, conscious opportunity seeking, time, and proceeding with a hypothesis. The study found a significant relationship between these components and managers' strategic thinking and personal readiness for strategic change in the Mashhad Municipality.

Monnavarian et al. (2011) analysed the use of twelve factors in their investigation of 196 individuals in different branches of the Benetton Company located in Tehran (the capital city of Iran) to study the strategic thinking processes. These factors included creativity and attention to the past, present and future, organic structure organization, environment analysis, conflict management, awareness of the situation, futuristic approach, intelligence, diversified mind pattern, accountability, organizational climate and coordination, systematic thinking, and process approach. The study found that these elements of strategic thinking are relevant and meaningful but that their priority is not equal. In terms of involvement in the strategic thinking process, the study found that the most used items of strategic thinking are environment analysis, with intelligence, creativity and attention to the past, present and future.

Halis et al. (2010) evaluated the effects of strategic thinking skills in four and five-star hotels in Istanbul, Turkey via a study of the thoughts of hotel managers. The purpose of this study was to investigate the influence of these skills on the process of strategic planning, as well as the influence of the strategic planning process on customers' satisfaction. The study identified three cognitive processes (strategic thinking skills). These skills included systems thinking, reframing and reflecting, while the strategic planning process included the content of the strategic action plan, stakeholder analysis and participation, the existence of an action plan, and performance measurement.

\section{Research methods}

\subsection{Research population and sample}

The population of this research consists of all the industrial shareholding companies in Jordan, which are registered on the Amman Stock Exchange (ASE). The entire population, which consisted of seventy-five industrial companies, was included in the study. Therefore, the population is the same as the sample (Ghauri and Gronhaug, 2010). The background information about the targeted companies was obtained via a personal visit to the Amman Stock Exchange.

A self-administered questionnaire was the main data collection method. Three levels of management - high level, middle level and low level - received the questionnaire. The three levels of management are the most appropriate ones to provide valid responses to questions relating to the strategic thinking process (Moon, 2013; Monnavarian et al., 2011; Goldman and Casey, 2010; Halis et al., 2010; Gilmore, 2007; Bonn, 2005; Pisapia et al., 2005; O'Shannassy, 2003; Bonn, 2001; O’Shannassy, 2000). For instance, Bonn (2005) argued that the social context in which the employee operates affects the practice of strategic thinking. Moreover, the application of strategic thinking can be accomplished by sharing views from different levels of management in the organizational structure, which aim to foster strategic thinking among the top team and to encourage all individuals to be involved in the development of innovative or creative ideas and strategies (Bonn, 2005; Bonn, 2001; O'Shannassy, 2000).

The questionnaire is in two parts. Part 1 provides general background information about the respondents and the characteristics of participants, which were industrial shareholding companies. Part 2 provides data on the practice of strategic thinking through three strategic thinking skills (systems thinking, reflective thinking, and 
reframing thinking). 225 questionnaires were distributed to the three levels of management in 75 listed industrial companies on the Amman Stock Exchange. 117 valid responses were obtained from 39 companies. The active response rate was, therefore, 52 per cent, which is a good one since response rates between 30 per cent and 50 per cent are typical for hand delivered and hand collected questionnaires (Saunders et al, 2009). It is also comparable to previous studies undertaken in the same country (Anchor and Aldehayyat, 2016; Aldehayyat, 2011; Aldehayyat, et al. 2011; Aldehayyat and Anchor, 2008).

\subsection{Profile of respondents}

51 per cent of respondents were over 40 years of age, 85.5 per cent were male, 6 per cent of them had less than five years working experience in their current position and 54.7 per cent had a total experience of more than 13 years. 84.6 per cent of respondent companies were under 50 years of age. 71 per cent of respondents represented small companies (less than 500 employees), 18 per cent of respondents represented medium sized companies (from 5001999 employees) and 10 per cent represented large companies of more than 2000 employees. The ownership types were 15.4 per cent Government or partnership with the private sector and 84.6 per cent private companies. In this study, the number of employees is the measure of company size, which is in line with a number of analagous studies in the field of strategy (Anchor and Aldehayyat, 2016; Aldehayyat, 2011; Aldehayyat and Anchor, 2010; Aldehayyat and Anchor, 2008; Gibbons and O’Connor, 2005; Stonehouse and Pemberton, 2002; Segev, 1989).

\subsection{Measures}

The questionnaire consists of 30 items in three sets of questions related to strategic thinking skills. The first set of questions examines the use of reflecting thinking skills. Respondents were asked, on a five-point scale ranging from "almost never" to "frequently", about the use of reflecting thinking skills. The second set of questions examines the use of reframing thinking skills. Respondents indicated, on a five-point scale ranging from "almost never" to "frequently", the extent of the use of each of the nine reframing thinking skills. In the third set of questions, respondents indicated, on a five-point scale rating from "almost never" to "frequently", the extent of the use of each of the eleven systems thinking skills.

\section{Results}

The use of reflecting skills was measured by a group of ten questions which were established on a five point Likert scale ( $1=$ Almost never, $2=$ Once in a while, $3=$ Sometimes, $4=$ Often and $5=$ Frequently $)$. The mean for each scale was over three, which reflects a high level of use for every activity (Table 1).

Tab. 1: The use of reflecting thinking skills $(n=117$ questionnaires $)$

\begin{tabular}{|c|c|c|}
\hline Reflecting thinking skills & Mean* & SD \\
\hline 1. Ask "why" questions in order to develop an understanding of problems. & 3.52 & 6 \\
\hline 2. Try to apply your experience and knowledge to any problem. & 4. & 731 \\
\hline $\begin{array}{l}\text { 3. Accept that your preferable beliefs could be mistaken when thinking about what you } \\
\text { have done and the decisions you have made in solving a problem. }\end{array}$ & 3.56 & 0.834 \\
\hline 4. Acknowledge the limitations of your own perspective. & 3.47 & 0.847 \\
\hline $\begin{array}{l}\text { 5. Discover how you could have handled a situation better when thinking } \\
\text { decision you have made. }\end{array}$ & 3.76 & 0.806 \\
\hline $\begin{array}{l}\text { 6. Try to find a common goal that will allow t } \\
\text { competing or in conflict both to succeed. }\end{array}$ & 3.64 & 1.013 \\
\hline $\begin{array}{l}\text { 7. Try to take into account the use of information gathered by experience, in tl } \\
\text { the problem. }\end{array}$ & 4.03 & 0.793 \\
\hline $\begin{array}{l}\text { 8. Seek coaching by colleagues or professionals when thinking about past decisions that } \\
\text { you have made. }\end{array}$ & 3.59 & 0.892 \\
\hline $\begin{array}{l}\text { 9. Try to take into account the real life implications when thinking about decisions and } \\
\text { actions you have made. }\end{array}$ & 3.81 & 0.809 \\
\hline 10. Seek to frame problems from & 3.62 & 0.838 \\
\hline Reflecting thinking skills & & \\
\hline \multicolumn{3}{|c|}{$\begin{array}{l}\text { The mean is an average of scale } 1=\text { almost never } 5=\text { frequently } \\
\text { A significant negative correlation exists between the age of the company and the use of one reflecting thinkin } \\
\text { ll: "Try to take into account the real life implications when thinking about decisions and actions you hav } \\
\text { de". The use of reflecting thinking skills has three negative and one positive relationship with the size of th } \\
\text { npany respectively. The use of reflecting thinking skills has two positive significant differences with the tw } \\
\text { es of ownership: "Ask "why" questions in order to develop an understanding of problems" and "Try to appl. } \\
\text { ir experience and knowledge to any problem" (Table 2). }\end{array}$} \\
\hline
\end{tabular}


Tab. 2: The correlation between the use of reflecting thinking skills and the age of the company, employee numbers (size of company) and ownership ( $\mathrm{n}=117$ questionnaires)

\begin{tabular}{llll}
\hline Reflecting thinking skills & $\begin{array}{l}\text { Company Age } \\
\text { Spearman'srho } \\
\text { (two-tailed) } r(p)\end{array}$ & $\begin{array}{l}\text { Company Size } \\
\text { Spearman's rho } \\
\text { (two-tailed) } r(p)\end{array}$ & $\begin{array}{l}\text { Company Ownership } \\
\text { Mann-Whitney } U \\
\text { (two-tailed) }(p)\end{array}$ \\
\hline Reflecting thinking skills 1: & $-0.770(0.411)$ & $-0.279(0.002)$ & $626.500(0.033)$ \\
Reflecting thinking skills 2: & $0.950(0.306)$ & $-0.220(0.017)$ & $650.000(0.046)$ \\
Reflecting thinking skills 3: & $-0.187(0.044)$ & $-0.311(0.001)$ & $751.000(0.255)$ \\
Reflecting thinking skills 4: & $-0.131(0.158)$ & $0.030(0.749)$ & $873.000(0.884)$ \\
Reflecting thinking skills 5: & $0.940(0.314)$ & $-0.054(0.564)$ & $725.500(0.248)$ \\
Reflecting thinking skills 6: & $0.061(0.511)$ & $-0.042(0.654)$ & $881.500(0.940)$ \\
Reflecting thinking skills 7: & $0.151(0.104)$ & $0.081(0.387)$ & $686.500(0.093)$ \\
Reflecting thinking skills 8: & $0.138(0.139)$ & $0.023(0.802)$ & $678.000(0.090)$ \\
Reflecting thinking skills 9: & $0.208(0.024)$ & $-0.025(0.786)$ & $668.000(0.070)$ \\
Reflecting thinking skills 10: & $0.125(0.178)$ & $0.290(0.001)$ & $828.000(0.613)$ \\
\hline
\end{tabular}

The greatest use of reframing thinking skills was in relation to "Try to create and evaluate a larger number of possible solutions and perceptions when the problem is more complex". This next greatest use related to "Engage in discussions with those who hold a different world view and different beliefs" and "Try to use different points of view to map out different strategies needed for the resolution of a problem". The least used was in relation to "Try to create a pre-conceived solution to a situation before it has been clearly defined or understood" and "Examine a problem by using one viewpoint" (Table 3 ).

Tab. 3: The use of reframing thinking skills $(n=117$ questionnaires $)$

\begin{tabular}{|c|c|c|}
\hline Reframing thinking skills & Miean & $\mathrm{SD}$ \\
\hline $\begin{array}{l}\text { 1. Try to create and evaluate a larger number of possible solutions and perceptions when } \\
\text { the problem is more complex. }\end{array}$ & 4.04 & 712 \\
\hline those who hold a different worldview and different beliefs. & 3.91 & 0.881 \\
\hline tion by using various viewpoints. & 3.82 & 0.784 \\
\hline $\begin{array}{l}\text { 4. Try to use different points of view to map out different strategies needed for the } \\
\text { resolution of a problem. }\end{array}$ & 3.91 & 0.799 \\
\hline $\begin{array}{l}\text { create a pre-conceived solution to a situation before it has been clearly defined or } \\
\text { od. }\end{array}$ & 2.78 & 135 \\
\hline 6. Tra & 3.18 & .164 \\
\hline 7. Ex & 2.50 & 11 \\
\hline $\begin{array}{l}\text { d engagement in discussions with critics especially with those who make } \\
\text { nptions about a situation. }\end{array}$ & 2.80 & 1.052 \\
\hline lue and create plans t & 3.25 & .946 \\
\hline Reframing thinking skills & & \\
\hline \multicolumn{3}{|c|}{$\begin{array}{l}\text { * The mean is an average of scale } 1=\text { Almost never } 5=\text { frequently } \\
\text { The correlation between the age of a company and the use of reframing thinking skills has one positive } \\
\text { elationship and two negative relationships. These are "Engage in discussions with those who hold a different } \\
\text { vorldview and different beliefs", "Examine a problem by using one viewpoint" and "Try to avoid engagement in } \\
\text { liscussions with critics, especially with those who make different assumptions about a situation". No statistically } \\
\text { ignificant differences exist between the size of company and the use of reframing thinking skills. The use of } \\
\text { eflecting thinking skills has two significant positive differences with the two types of ownership respectively: } \\
\text { "Engage in discussions with those who hold a different world view and different beliefs" and "Examine a situation } \\
\text { ysing various viewpoints" (Tab. 4). }\end{array}$} \\
\hline
\end{tabular}


Tab. 6: The correlation between the use of systems thinking skills and company age, company size (number of employees) and ownership ( $\mathrm{n}=117$ questionnaires)

\begin{tabular}{llll}
\hline Systems thinking skills & $\begin{array}{l}\text { Company age } \\
\text { Spearman's rho } \\
\text { tailed) } r(p)\end{array}$ & $\begin{array}{l}\text { Company size } \\
\text { (two- }\end{array}$ & $\begin{array}{l}\text { Spearman's rho } \\
\text { tailed) } r(p)\end{array}$ \\
\hline Systems thinking 1: & $-0.129(0.166)$ & $-0.113(0.225)$ & $\begin{array}{l}\text { Mann-Whitney } U \text { (two- } \\
\text { tailed) }(p)\end{array}$ \\
Systems thinking 2: & $0.092(0.324)$ & $-0.014(0.878)$ & $662.500(0.006)$ \\
Systems thinking 3: & $0.171(0.065)$ & $0.117(0.209)$ & $653.000(0.034)$ \\
Systems thinking 4: & $-0.002(0.983)$ & $0.197(0.033)$ & $794.500(0.440)$ \\
Systems thinking 5: & $-0.011(0.903)$ & $0.049(0.596)$ & $873.000(0.659)$ \\
Systems thinking 6: & $0.028(0.767)$ & $0.329(0.000)$ & $672.500(0.073)$ \\
Systems thinking 7: & $0.120(0.023)$ & $0.118(0.204)$ & $577.500(0.011)$ \\
Systems thinking 8: & $0.189(0.042)$ & $-0.049(0.597)$ & $542.000(0.004)$ \\
Systems thinking 9: & $0.054(0.566)$ & $-0.210(0.023)$ & $386.500(0.000)$ \\
Systems thinking 10: & $0.119(0.203)$ & $-0.006(0.951)$ & $718.000(0.162)$ \\
Systems thinking 11: & $0.011(0.905)$ & $-0.102(0.272)$ & $788.500(0.422)$ \\
\hline
\end{tabular}

\section{Discussion}

\subsection{Reflecting skills}

The findings indicate that Jordanian industrial companies believe in the ability of reflecting thinking skills to enhance their experience and knowledge and thereby lead to the solution of a problem. The findings indicate also that Jordanian industrial companies create a balance between actual reflections and the strategic decisions that they have made. In this context, the findings showed that the use of reflecting thinking skills scored 3.72 overall. Trying to take into account the use of information gathered by experience in the solution of a problem scored 4.03. The lowest score recorded is "acknowledging the limitations of your own perspective" (3.47). The mean values of all skills are relatively close to one other. This result may be due to the homogeneity of the age of the participants, their education level, their management level and their work experience. 51.3 per cent were over 40 years of age and 29.1 per cent were from 36 to 40.75 .2 per cent had a Bachelor degree as their highest qualification while 12.0 per cent had a Master degree as their highest qualification. 47.0 per cent were top-level managers while 51.3 per cent were middle level managers. 24.8 per cent had 9-12 years' work experience while 54.7 per cent had 13+ years' work experience.

Pisapia et al. (2009) found that there is a relationship between the age of their respondents and the use of reflective thinking skills and that the group aged 20-25 years used reflective thinking skills but less than the other categories in their sample study, which meant that the use of these skills increased with the age of employees. Karğin and Aktaş (2012) found that the use of reflective thinking skills related to education level (i.e. possession of a Bachelor's degree) and a higher usage of reflecting thinking skills by CPA Certified Public Accountant trainees in Turkey compared to Certified Public Accountants (CPAs). The use of reflecting skills for CPA trainees was higher than for CPAs. The findings also are consistent with those of Pang and Pisapia (2012) who found that the use of reflecting skills is a function of education and training, with those Hong Kong School leaders who held higher degrees practising it more than those with lower degrees do.

The results show no statistically significant correlation between the use of reflecting thinking skills and the age of the company. That is to say, the age of the company did not affect or determine participants' involvement in the practice of reflecting thinking skills. The ability of Jordanian industrial companies to practice reflecting thinking skills may depend on its age: 69.2 per cent of companies were between 20 and 49 years old. In addition, these companies may recruit personnel who have previous experience of the use of strategic thinking skills.

The findings show less statistically significant relationships between the use of reflecting thinking skills and the size of the company. This finding is consistent with Stonehouse and Pemberton (2002) who did not find a relationship between the practice of strategic thinking and organisational size in medium and small size SMEs companies in the UK, but did so in larger size companies. Jordanian companies are similar in size to the SMEs in Stonehouse and Pemberton (2002)'s sample.

Companies in different types of ownership did not differ in their use of reflecting thinking skills. This may be because the managers of both types of company are mainly Jordanian. This finding is consistent with Karğin and Aktaş (2012) who found that the use of reflecting thinking skills differed by work position for both CPAs and CPA trainees. Their study found no relationship between the use of reflecting thinking skills and age, work experience, education level or gender for both groups.

\subsection{Reframing Skills}

The findings indicate that the majority of Jordanian industrial companies have a relatively high commitment to the 
use of reframing thinking skills and try to use different ways to map out the different strategies needed to solve problems. These ways include creating different solutions and perceptions, examining different viewpoints, discussions with employees from different management levels, and holding different beliefs, to solve a problem. The use of reframing thinking skills recorded an overall mean of 3.55. These findings showed that Jordanian industrial companies make considerable use of reframing thinking skills to find different alternatives to solve a problem. Moreover, the study showed that the use of the activity "trying to create and evaluate a larger number of possible solutions and perceptions when the problem is more complex" recorded the highest score, 4.04, while the lowest rank recorded was in the use of examining a problem by using one viewpoint, with a score of 2.50 . This finding is consistent with Karğin and Aktaş (2012) who found greater use of reframing thinking skills by CPA trainees in Turkey compared to CPAs.

The findings show that the use of reframing thinking skills has three negative relationships with the age of industrial companies. This means that some older companies who may not believe in the benefits of strategic thinking engage less in the practice of reframing thinking skills than those who believe in its benefits. That is to say, the age of listed industrial companies did not affect or determine the participants' use of reframing thinking skills. This could be because the majority of industrial companies are nearly the same age (i.e. less than 50 years of age (84.6 per cent) and those companies were not facing difficulties in practicing reframing thinking skills at different levels in their companies.

The size of the company did not determine the participants' involvement in the use of reframing thinking skills. This finding is consistent with Stonehouse and Pemberton (2002) who did not find a relationship between the practice of strategic thinking and the size of the company in medium and small size SMEs in the UK but did so in larger size companies. Jordanian companies are similar in size to the SMEs in Stonehouse and Pemberton (2002)'s sample.

Karğin and Aktaş (2012) did not find a statistically significant relationship between the use of reframing thinking skills and age, gender, work experience and education level. However, they did find statistically significant differences between work position and the use of reframing thinking skills.

The findings of this study show no statistically differences between the two types of ownership for seven out of nine of the reframing thinking skills. That is to say, the nature of ownership did not affect or determine the participants' involvement in the use of reframing thinking skills. This may be due in part to the fact that the managers from different levels are overwhelmingly Jordanian. In addition, the cultures of their companies are participative, they are willing to share information with middle and lower management, and they are willing to share responsibility for their decisions.

\subsection{Systems Thinking Skills}

The results indicate that Jordanian industrial companies put more emphasis on the use of systems thinking skills and the mean for all activities of involvement in the use of systems thinking as a cognitive skill was more than three (3.67) and this indicates a relatively high level of participation in the use of systems thinking skills by Jordanian industrial companies. That is to say, there was a use of systems thinking skills by a majority of Jordanian industrial companies and they believe in its benefits through involvement in all of its activities. A number of other studies of strategic thinking have reported similar results. El-Farra et al. (2008) and El-Farra (2009) found a relatively high use of systems thinking skills amongst Ministry of Health managers in different divisions in the Gaza Strip and in non-governmental leadership in Gaza Province. Psiapia et al. (2009) found that four universities in the United States, Hong Kong, Shanghai and Malaysia made extensive use of systems thinking skills with only a small variance in the level of use from country to country. Karğin and Aktaş (2012) found that CPA trainees in Turkey used system thinking more than CPAs.

The results show two statistically significant differences between company age and involvement in systems thinking skills. There was only one positive correlation out of eleven between the participants' involvement in systems thinking skills and the size of the company. Therefore, neither age nor size of company affected or determined the use of systems thinking skills in Jordanian listed industrial companies. The findings show five positive statistical relationships between the type of ownership and the use of systems thinking skills.

Karğin and Aktaş (2012) also found no relationship between the usage of systems thinking skills and certain managerial factors (i.e. age, work experience, education level and gender) in their study. Moreover, El-Farra et al. (2008) reported a similar finding in a Middle Eastern context. They found no significant differences between Primary Health Care and Hospitals in the Gaza Strip in the practice of systems thinking because general managers, managers and heads of department of both Directorates were similar in their level of education (they held at least a Bachelor degree). They also found no significant relationship between involvement in systems thinking and the size of division, governorate, qualifications and experience in the Ministry of Health in the Gaza Strip. However, El-Farra (2009) found no significant relationship between involvement in systems thinking and age and gender among the non-governmental leadership in Gaza Province. This might relate to the participants' similar education level, as the vast majority (85.5 per cent) of them held at least a Bachelor degree. 


\section{Conclusions}

Strategy scholars have asserted that strategic thinking is an important process for enhancing competitive advantage in industrial companies. However, there has been limited research to date on strategic thinking in industrial companies in emerging market contexts, particularly in the Middle East. This study attempts to fill the gap in the literature by providing a better understanding of the nature and practice of strategic thinking in listed Jordanian industrial companies. This is the first such study and is one of the first in the Middle East. The study explores the practice of strategic thinking in Jordanian listed companies and identifies the information sources of the skills used in strategic thinking. The study investigates the effect of company age, company size and type of ownership on the extent of the use of strategic thinking skills (i.e. reflecting, reframing and systems thinking skills).

Jordanian listed industrial companies practice extensively strategic thinking skills (i.e. reflecting, reframing and systems thinking skills). The companies use reflecting and systems thinking skills uniformly. However, they exercise greater discretion in the use of reframing skills. This may relate to the similarity in age, experience and education level of the respondents. Pang and Pisapia (2012) and Pisapia et al. (2009) concluded in their study that the use of strategic thinking skills increases with age and experience - the younger you are the less you use strategic thinking skills. This study provides an insight into the relationship of the practice of strategic thinking with certain organizational characteristics (age, size and type of ownership). However, more investigation is needed to find out the relationship between managerial characteristics and the practice of strategic thinking in Jordanian industrial companies, although there are indications that companies pay more attention to achieving them at different levels of management.

Although the findings of the study have some generalisability, they do have two limitations. First of all, the nature of this research is descriptive and the method used is a cross-sectional survey. This does not provide the opportunity to explore in more depth some of the areas related to the practice of strategic thinking in Jordanian companies. An in-depth type of study that focuses on a smaller number of respondents, as well as a smaller number of these companies, should be used in future research. The second limitation is the study's concentration on Jordanian industrial companies listed on the Amman Stock Exchange. This may affect negatively the generalizability of the findings to other types of businesses, which operate outside the Amman Stock Exchange (e.g. medium and small size businesses). The relationship between strategic thinking and the culture, structure, performance and decision making of medium and small size industrial businesses in Jordan should be investigated in future research.

In spite of these limitations, this study does provide findings which help to understand the extent of the use of strategic thinking in Jordanian industrial companies. It also provides information regarding the relationship between the practice of strategic thinking and certain organizational characteristics (company age, size, and type of ownership). It can be concluded from the findings that Jordanian industrial companies are still crafting their strategic architecture.

\section{References}

Abraham, S. (2005), Stretching strategic thinking. Strategy \& Leadership, 33(5), pp. 5-12.

Aldehayyat, J. (2011), Organizational characteristics and the practice of strategic planning in Jordanian hotels. International Journal of Hospitality Management, 30(1), pp.92-199.

Aldehayyat, J. A. Al Khattab, A. Anchor, J. (2011). The use of strategic planning tools and techniques by hotels in Jordan. Management Research Review, 34(4), pp. 477-490.

Aldehayyat, J. and Anchor, J. (2008), Strategic Planning Tools and Techniques in Jordan: Awareness and Use. Strategic Change, 17(7-8), pp. 281-293.

Aldehayyat, J. and Anchor, J., (2010). Strategic planning implementation and creation of value in the firm. Strategic Change, 19(3-4), pp. 163-176.

Allio, R. (2006). Strategic thinking: the ten big ideas. Strategy and Leadership, 34(4), pp.4-13.

Alsallem, M. (2005). The Basics of Strategic Management. Amman, Jordan: Darwael Press.

Al-Zu'bi, H. (2016). Strategic thinking Competencies and their Impact on Strategic Flexibility. Journal of Current Research Science, 4(1), pp. 35-39.

Amman Trade Point. (2009). General Information about Jordan. The information available at : $<$ http://www.jedco.gov.jo/atp/index.php?option=com_content\&view=article\&id=2\&Itemid=3\&lang=en $>$ accessed [26/05/2013].

Anchor J. and Aldehayyat J. (2016), Strategic decision implementation in an emerging market, Management Decision, 54(3), pp. 646-663.

Baloch, Q. and Inam, M. (2007), Strategic Thinking: Catalyst to Competitive Advantage. Journal of Managerial Sciences, 1(2), pp. 1-26.

Bonn, I. (2001), Developing strategic thinking as a core competency. Management Decision, 39(1), pp. 63-70.

Bonn, I. (2005), Improving Strategic Thinking: a multilevel approach. Leadership and Organization Development Journal, 26(5), pp.336-354. 
Bonn, I. and Christodoulou, C. (1996), From Strategic Planning to Strategic Management. Long Range Planning, 29(4), pp. 543-551.

Casey, A. and Goldman, E. (2010), Enhancing the ability to think strategically: a learning model. Management Learning, 41(2), pp. 167-185.

Department of Statistics Jordan. (2017), Jordan Population, The information available [on line] at: < http://dosweb.dos.gov.jo/population/population-2/> accessed [10/9/2018].

El-Farra, M. (2009). The Level of Strategic Thinking among Non-Governmental Leadership in Gaza Province, Journal of Al Al-Rafedeen Development-Iraq, Vol. 95, No. 31, pp. 33-59. The article is available [on line] at: $<$ http://www.iasj.net/iasj?func=fulltext\&aId=33686> accessed [10/9/2016].

El-Farra, M., Juda, M. and Nafeh, B. (2008), Strategic Thinking at the Ministry of Health in the Gaza Strip: Management Viewpoint. Journal of Al Azhar Unversity-Gaza, Humanities Sciences, Vol. 10, No. 1, pp. 2148. The article is available [on line] at: www.alazhar.edu.ps/juornal123/detailsr.asp?scqq1=863 [3/07/2012].

Gallen, T. (2006), Managers and strategic decisions: does the cognitive style matter? Journal of Management Development, 25(2), pp. 118-133.

Ghauri, P.and Gronhaug, K. (2010), Research Methods in Business Studies. ${ }^{\text {th }}$ Edition, London: Financial Times Prentice Hall.

Ghorbani, M. and Kiani, B. (2012).The relationship Between Strategic Thinking of Managers and Readiness for Strategic Transformation, Middle-East Journal of Scientific Research, 11(8), pp. 992-1002.

Gibbons, P. and O’Connor, T. (2005), Influences on strategic planning processes among Irish SMEs, Journal of Small Business Management, 43(2), pp. 170-186.

Gilmore, B. (2007), Integrating Strategic Thinking into your Organization for Long-Term Competitive Advantage. Leadership Advance Online- Issue XI, The information is available [on line] at: $<$ http://www.regent.edu/acad/global/publications/lao/issue_11/gilmore.htm> accessed [30/06/2018].

Goldman, E. (2008), The Power of Work Experiences: Characteristics Critical Developing Expertise in Strategic Thinking. Human Resource Development Quarterly, 19(3), pp. 217-239.

Goldman, E. (2009), Experiences That Develop the Ability to Think Strategically. Journal of Healthcare Management, 54(6), pp. 403-417.

Goldman, E. and Casey, A. (2010), Building a Culture that Encourages Strategic Thinking. Journal of Leadership \& Organizational Studies, 17(2), pp. 119-128.

Goldman, E. Scott, A., and Follman M. (2015), Organizational practices to develop strategic thinking. Journal of Strategy and Management, 8(2), pp. 155-175.

Goldman, E. Scott, A. M. (2016), Competency models for assessing strategic thinking. Journal of Strategy and Management, 9(3), pp. 258-280.

Graetz, F. (2002), Strategic thinking versus strategic planning: towards understanding the complementarities. Management Decision, 40(5), pp. 456-462.

Halis, M., Sariisik, M. and Turkay, O. (2010), Institutional Strategic Consciousness and its Reflections: Research on Qualified Hotels in Istanbul. Journal of Global Strategic Management, 4(2), pp. 160-170.

Hamel, G. and Prahalad, C. K. (1994), Competing for the Future. Boston, USA: Harvard School Press.

Heracleous, L. (2003). Strategy and Organization: Realizing Strategic Management. Cambridge, United Kingdom: Cambridge University Press.

Heracleous, L., (1998). Strategic Thinking or Strategic Planning? Long Range Planning 31(3), pp. 481-487.

Index of Economic Freedom Score (2013) Jordan's economic freedom score. The information available [on line] at: <http://www.heritage.org/index/pdf/2013/countries/jordan.pdf > accessed [19/05/2013].

Jelenc, L. and Swiercz, P.M. (2011), Strategic thinking capability: Conceptualization and measurement. The 56th Annual ICSB World Conference, Stockholm, Sweeden, 15-18 June, 2011, the information available [on line] at $:<\mathrm{http}: / /$ www.icsb2011.org/download/18.62efe22412f41132d41800012398/310.pdf > accessed [20/02/2013].

Karğin, S. and Aktaş, R. (2012), Strategic Thinking Skills of Accountants during Adoption of IFRS and the new Turkish Commercial Code: A survey from Turkey. Social and Behavioral Sciences, 58, pp. 128-137.

Karimi, E., Aslizadeh, A. and Khalilinaghadeh, M. (2014). An Investigation of The Impact of Competitive and Global Approach on Strategic Thinking of Managers of Tehran Shahidtondgoyan Oil Refining Company. International Journal of Current Life Sciences, 4(1), pp.84-87.

Kaufman, R. (1991). Strategic planning plus: an organizational guide. Glenview, IL: Scott Foresman.

Khalili, K., Armani, M., Rahimi, H., Jamshidi, F., and Jamshidi, Z. (2015). The Role of Strategic Thinking in Organizational Performance: A Case Study of the Municipality of Ilam. International Journal of Review in Life Sciences, 5(8), pp. 56-62.

Kutschera, I. and Ryan, M. (2009). Implications of Intuition for Strategic Thinking: Practical Recommendations for Gut Thinkers. SAM Advanced Management Journal, 74(3), pp. 12-20.

Lawrence, E. (1999). Strategic Thinking: A Discussion Paper. Public Services of Commission of Canada. The 
information is available [on line] at: <www.theraffettogroup.com /Strategic Thinking: Discussion paper.pdf.> accessed [16/01/2010].

Liedtka, J. (1998a), Strategic thinking: Can it be taught? Long Range Planning, 31(1), pp. 120-129.

Liedtka, J. (1998b), Linking Strategic Thinking with Strategic Planning. Strategy and Leadership, 26(4), pp. 3035 .

Mainardes, E.W.,Ferreira, J.J., and Raposo, M.L. (2014), Strategy and Strategic Management Concepts: are they recognised by Management Students?. E\&M Ekonomie a Management, 17(1), pp.44-61. http://dx.doi.org/10.15240/tul/001/2014-1-004

Mason, J. (1986). Developing Strategic Thinking. Long Range Planning, 19(3), pp. 72-80.

Matheson, D. and Matheson, E. (2001), Smart Organizations Perform Better. Research-Technology Management, 44(4), pp. 49-54.

Mintzberg, H. (1994a), The Rise and Fall of Strategic Planning. London, United Kingdom: Prentice Hall.

Mintzberg, H. (1994b), The Fall and Rise of Strategic Planning. Harvard Business Review, 72(1), pp. 107-114.

Monnavarian, A., Farmani, G. Yajam, H. (2011), Strategic thinking in Benetton. Business Strategy Series, 12(2), pp. $63-72$.

Moon, B. (2013), Antecedents and outcomes of strategic thinking. Journal of Business Research, 66(10), pp. 16981708.

O'Shannassy, T. (1999), Strategic Thinking: A Continuum of Views and Conceptualisation. RMIT School of Business, The information is available [on line] at: <.mams.rmit.edu.au /5rbhieqtd50.pdf.> accessed [11/01/2010].

O'Shannassy, T. (2000), Models and methodology to study strategic thinking in Australian Public Companies. RMIT University, School of Management, The information is available [on line] at: $<$ http://mams.rmit.edu.au/xdcktyrvbihz.pdf $>$ accessed [30/06/2011].

O'Shannassy, T. (2001), Lessons from the Evolution of the Strategy Paradigm. Journal of the Australia and New Zealand Academy of Management, 7(1), pp. 25-37.

O'Shannassy, T. (2003), Modern Strategic Management: Balancing Strategic Thinking and Strategic Planning for Internal and External Stakeholders. Singapore Management Review, 25(1), pp. 53-67.

Pang, N. S. and Pisapia, J. (2012), The Strategic Thinking Skills of Hong Kong School Leaders: Usage and Effectiveness. Educational Management Administration \& Leadership, 40(3), pp. 343-361.

Pisapia, J. (2009). The Strategic Leader. The information is available [online] at : $<$ http://slideshare.net/jpisapia/strategic-thinking-skills $>$ accessed [22-6-2018].

Pisapia, J., Ellington, L., Toussaint, G. and Morris, J. (2011), Strategic Thinking Skills: Validation and Confirmation of Constructs. The information is available [on line] at: $<$ http://www.academia.edu/755209/Strategic_Thinking_Skills_Validation_and_Confirmation_of_Construct s> accessed [25/2/2018].

Pisapia, J., Pang, N., Lin, Y. and Morris, J. (2009), A Comparison of the Use of Strategic thinking Skills of Aspiring School leaders in Hong Kong, Malaysia, Shanghai, and the United States: An Exploratory Study. International Education Studies, 2(2), pp.46-58.

Pisapia, J., Reyes-Guerra, D. and Coukos-Semmel, E. (2005), Developing the Leader's Strategic Mindset: Establishing the Measures. Leadership Review, 5(1), pp. 41-68.

Raimond, P. (1996), Two Styles of Foresight: Are We Predicting the Future or Inventing It? Long Range Planning. 29(2), pp. 208-214.

Salih, A., and Alnaji, L. (2014), Impact of Strategic Thinking and Strategic Agility on Strategic Performance: A Case Study of Jordanian Insurance Industry Companies. International Review of Management and Business Research, 3(4), pp. 1871-1882.

Saunders, M., Lewis, P., and Thornhill, A. (2009), Research Methods for Business Students, $5^{\text {th }}$ Edition, London,UK : Prentice Hall..

Segev, E. (1989). A Systematic Comparative Analysis and Synthesis of Two Business-level Strategic Typologies. Strategic Management Journal, 10(5), pp. 487-505.

Steiner, G., Kunin, H., and Kunin, E. (1983), Formal Strategic Planning in the United States Today. Long Range Planning, 16(3), pp. 12-17.

Stonehouse G., and Pemberton J. (2002), Strategic Planning in SMEs-some empirical findings. Management Decision, 40(9), pp. 853-861.

Tavakoli, I. and Lawton, J. (2005), Strategic thinking and knowledge management. Handbook of Business Strategy, 6(1), pp.155-160.

Torkamani, B. and Mymand, M. (2016), Investigation of the Relationship between Organizational Intelligence and Strategic Thinking and Determination of Its Role in Creation of a Mindful Organization: a Case Study Research. Mediterranean Journal of Social Sciences, 7(3), pp. 79-85.

Turkay, O., Halis, M., Sariisk, M. and Calman, I. (2012), Effects of strategic consciousness and strategic planning 
on business performance: a comparative study of the industries in Turkey. African Journal of Business Management, 6(32), pp. 9188-9201.

USAID/Jordan (2013), About Jordan: Country Profile. American Embassy, The information available [on line] at : <http://jordan.usaid.gov/en/About/Pages/default.aspx $>$ accessed [26/05/2013].

Wilson, I. (1994), Strategic Planning Isn’t Dead-It Changed. Long Range Planning, 27(4), pp. 12-24.

World Bank Group (2016). Jordan Overview, the information available [on line] at: <http://.data. worldbank.org/country/jordan> accessed [12/9/2018]. 